\title{
Critique on the Conceptual Developments of Innovative Practices with Lightweight Fills
}

\author{
Devapriya Chitral Wijeyesekera ${ }^{1, *}$, Nurvin Ratha ${ }^{1}$, and Alvin John Lim Meng Siang ${ }^{1}$ \\ ${ }^{1}$ Faculty of Civil and Environmental Engineering, Universiti Tun Hussein Onn Malaysia, Johor, \\ Malaysia
}

\begin{abstract}
Conceptual developments are underpinned by the intellectual process of constant reviewing and developing innovative research ideas into realistic design. There exists no one quick fix, fit for purpose solution to ensure stability of structures being constructed on a wide range of demanding ground conditions and variety of project constraints. Routine highway design and construction technology conformingly adopt only conventional fill methods and thus fail even to address adequately the less favoured conditions in challenging situations: a high initial construction cost arising from a full replacement of existing unfavourable soil conditions or an unsustainable construction design leading to a condition of rapid disintegration requiring regular expensive and disruptive highway maintenance activity. Undulating road embankment surfaces result from the transference of heavy self-weight of the embankment fill on yielding and non-uniform subgrade such as in peat soils. The Manitoba Water Services Board [1] specifies four classes of fills (viz; common, compacted common, compacted select granular backfill and unshrinkable backfill) for backfilling of pipeline trenches. Both conventional and alternatively sustainable backfills are discussed in this paper with new and appropriate technology opening doors with other tangible benefits for innovative and cost saving outcomes for differing construction scenarios.
\end{abstract}

\section{Introduction}

Sustainable infrastructure developments are vital socio-economic pathways that foster a better quality of life to all and in particular, for the less fortunate of a developing country's population. Competitiveness and the sustainability of the developed products and the technologies are additional parameters of information for the critique of conceptual design. Methods include the performance specifications method, quality function deployment (QFD), and morphological charts. Means include brainstorming, synectics, analogies, benchmarking, and reverse engineering.

Cost effective infrastructure construction is necessarily vital for the economic health of any country. This must be deemed a priority particularly in developing countries. Nearly linear infrastructures such as highways, rural roads, utility pipelines (and others such as power lines) desire to be post construction maintenance free. Daud et al [2] emphasised

* Corresponding author: dcwijey@gmail.com 
that the 'green road' approach to be the most appropriate for rural road construction in developing countries and be set in place through environmental friendly construction practice with optimum utilisation of local resources together with simple (self-help) technologies. Historically, the first documented road construction dates to 4000BC (stone paved roads in Ur, Middle East and Roman Corduroy Roads in Glastonbury, UK) and 3000 BC (brick paving in India) [3]. Emerging infrastructure projects such as routing of new highways demand construction to inevitably take place on less favourable soils, such as on soft yielding soils or on even cavernous rocks that require embankment fills.

Cracking of road pavements and sidewalks (Fig. 1(a) and 1(b)) are clear indicators of failure initiations and the presence of inherently imminent problems. Learning must extend beyond recognising a problem, to seek a better understanding of the cause of failure and recommend pragmatic, sustainable and lasting solutions. The conceptual development phase for any lasting solutions can be reverberantly time-consuming, depending on the level of expertise demanded for the investigation. Lightweight fills being the researched area, current engineering problems faced in transportation infrastructures and the potential methods to address those challenges is highlighted in this paper.

\section{Road pavement cracking as early failure indicators}

Roads with heavier loads need to be designed differently than the lower volume roads. Furthermore, paved roads flex excessively through fatigue in the spring (monsoonal weather, under surface seepage or flood situations) when it is softened through saturation. Some common types of pavement cracking are fatigue/ alligator cracking, longitudinal cracking, transverse cracking, block cracking, slippage cracking, reflective cracking and edge cracking [4] (Fig. 1). Sub grade softening occur through ingress of water into existing cracks, standing water on a road without a crown, piping of ground water or from leaking buried pipes. Longitudinal cracking parallel to the laydown direction are a type of fatigue cracking, but can also result from the lateral squeezing of the softened particulate subgrade through and into the unsupported side drains. Alligator cracking is characterised by interconnected / interlaced cracking in the asphalt layer (similar to that on an alligator hide). Crack sizes range between $150 \mathrm{~mm}$ and $300 \mathrm{~mm}$ in size and numerous factors such as subbase failure, poor drainage or repeated over loading can be the cause.

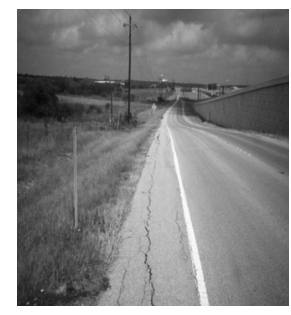

(a)

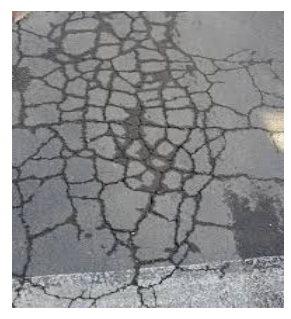

(b)

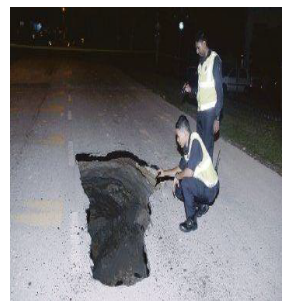

(c)

Fig. 1. Few examples of Road Pavement failures (a) Longitudinal Cracking (b) Alligator Cracking (c) Road collapse - Taman Kinara [5]

Fig. 1(c) echoes a report in New Strait Times, 2011 [5] of a not so uncommon road collapse that occurred catastrophically in Section 5, Taman Kinara, Batu 9, Jalan Puchong leaving a gaping sinkhole ( $6 \mathrm{~m}$ deep and $4 \mathrm{~m}$ wide). This is a characteristic sinkhole failure in the upper Silurian marble rock of the calcareous rock formation in Kuala Lumpur. Such failures emphasise the need for careful ground investigations even in Highway design and construction over presumed sound and "solid" rock geology. 


\subsection{Maintenance on the approach roads to Parit Yaani roadbridge}

On a hotly pursued research note, Fig. 2 gives location (coordinates 1.876205, 103.016594; on J125 - Jalan Parit Yaani/Seri Bengkal Kampung Sengkuang) where recurrent and costly maintenance of road pavement distress is being done. During 2010/2013, the road bridge over a minor tributary of Sungai Simpang Kanan was constructed on piled foundations driven into soft marine clay. The approach road to the reinforced concrete bridge has since been repaired six times (Nov 2013, Apr 2014, Sept 2014, Feb 2015, Aug 2015 and Feb 2016). Each time fresh conventional particulate fill (sometimes with reinforcing geomembranes) were placed. Fig. 2(c) and 2(d) taken now in October 2016 show the development of new transverse linear cracking at the crest of the approach road fills, resulting from continued self-weight settlement of the underlying soft marine clay.

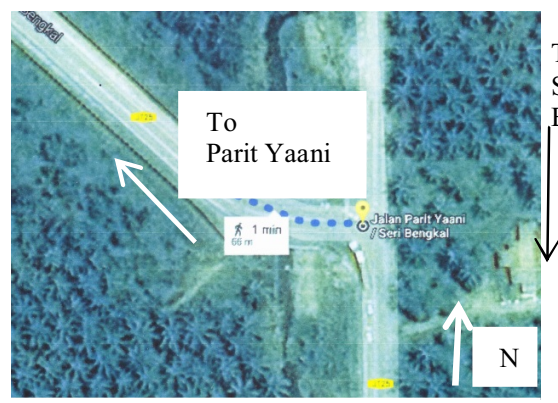

(a) Google View of the Bridge site

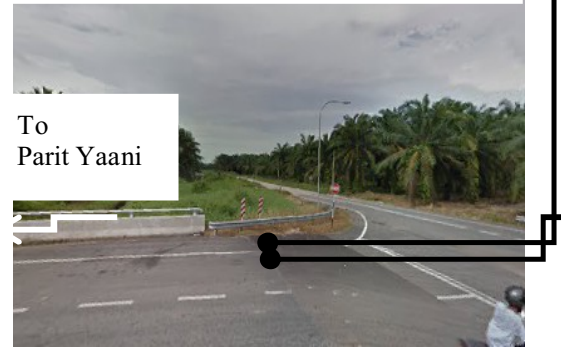

(b) View of the Bridge approach after 2013 repair

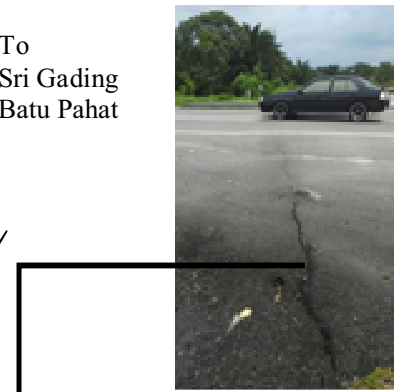

(c) and (d) Current views the Bridge approach

Fig. 2. Views of J125 - Jalan Parit Yaani/ Seri Bengkal Kampung Sengkuang

\subsection{Gravel roads - Extremes of problems}

On the other hand, unpaved rural roads pose their own suite of problems. As examples, poor drainage and construction can result in wash boarding effects (Fig. 3(a)) [6]. In dry weather conditions, unsealed gravel roads cause dust (Fig. 3(b)) which is an aggravating problem to the people who live nearby and to the wider environment. Chlorides of Calcium, Magnesium and even Sodium are being used as dust suppressant stabilisers.

\section{Conventional and natural fill material}

An embankment fill is a volume of earthen material that is placed and compacted for the purpose of raising the grade of a roadway (or railway) above the level of the existing ground surface, filling in a hole or depression. They are constructed of materials that usually consist of soil, including aggregate, rock or crushed paving material [8] and are 
used as bases in rural road construction or as a sub-base for flexible or rigid pavements, and are also used (bound or unbound) in the construction industry as trench backfills. Department of Transport (UK) specifies 2 types of granular materials (Type 1 and Type 2) for Road and Bridge Works. Type 1 is a well graded aggregate that is restricted to crushed rock, crushed concrete or well burnt non-plastic colliery shale (Fig. 4). Material that is finer than $425 \mu \mathrm{m}$ should necessarily be non-plastic. Type 2 additionally includes natural sand and gravel and the plasticity index of the material finer than $425 \mu \mathrm{m}$ is limited to $6 \%$. For use as a subbase it must have a minimum California Bearing Ratio (CBR) of 20\%, and needs to be protected from wet conditions.

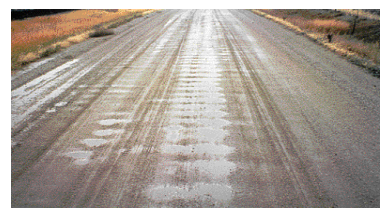

(a)

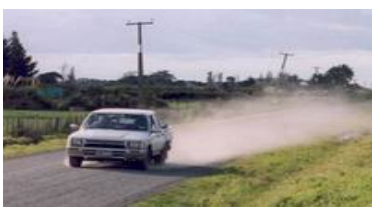

(b)

Fig. 3. Corrugation (wash boarding) in gravel roads having inadequate crown [6], and dust hazards from gravel roads during dry weather [7]

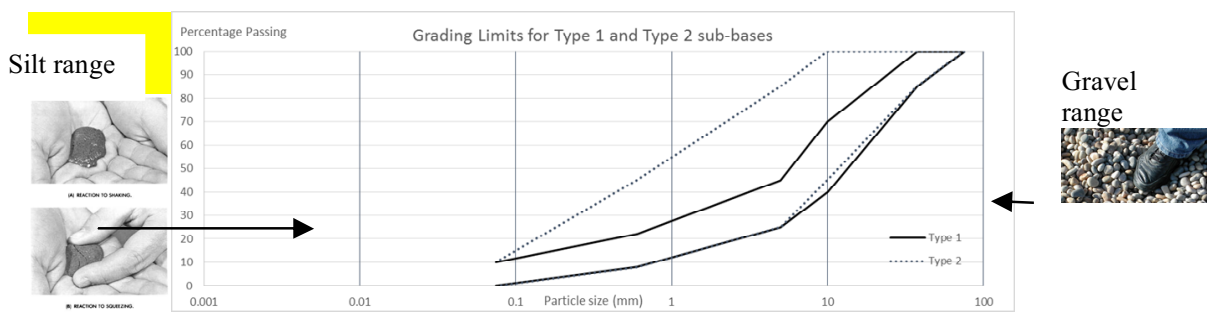

Fig. 4. Grading Curve Limits for Type 1 and Type 2 fill lying between silt and gravel

The durability of a pavement depends on the underlying subgrade soil (Fig. 5(a)). It shows that anything finer than sand gives a poor support with a clear decrease in CBR values. Fig. 5(b) [9] indicates the JKR guidelines for the selection of alternative pavement structures for low volume $(<1 \mathrm{~m}$ ESAL) roads.

\section{Alternative lightweight fill materials}

Wijeyesekera et. al. [11] describes the use of artificial aggregates (manufactured from Municipal Solid Waste) as an innovative, improved and sustainable trench backfill and bedding material for buried plastic pipes. Large quantities of postconsumer glass can be recycled and are being reused as crushed aggregate filler in mortars [12]. Table 1 is an overview of different alternative fills for road subgrades that are being pursued in contemporary research. 


\begin{tabular}{|c|c|c|c|c|c|}
\hline $\begin{array}{l}\text { Subgracle } \\
\text { Soils } \\
\text { for Design }\end{array}$ & $\begin{array}{c}\text { Unified Soil } \\
\text { Classifications }\end{array}$ & $\begin{array}{l}\text { Load Support and } \\
\text { Drainage Claracteristics }\end{array}$ & $\begin{array}{l}\text { Modulus of } \\
\text { Subgrade } \\
\text { Reaction (lk), } \\
\text { psi/inch }\end{array}$ & $\begin{array}{c}\text { Resilient } \\
\text { Modulus }\left(\mathbf{M}_{\mathrm{R}}\right) \\
\mathbf{p s i}\end{array}$ & $\begin{array}{c}\text { CBR } \\
\text { Range }\end{array}$ \\
\hline $\begin{array}{c}\text { Crushed } \\
\text { Stone }\end{array}$ & GW, GP, and GU & $\begin{array}{l}\text { Excellent support and } \\
\text { drainage characteristics } \\
\text { with no frost potential }\end{array}$ & 220 to 250 & $\begin{array}{l}\text { Greater than } \\
5700\end{array}$ & 30 to 80 \\
\hline Gravel & GW. GP. and GU & $\begin{array}{l}\text { Excellent support and } \\
\text { drainage charactersistics } \\
\text { with very slight frost } \\
\text { potential }\end{array}$ & 200 to 220 & 4500 to 5700 & 30 to 80 \\
\hline Silty gravel & $\begin{array}{c}\text { GW-GM, GP-GM. } \\
\text { and GM }\end{array}$ & $\begin{array}{l}\text { Good support and fair } \\
\text { draingege, characteristics } \\
\text { with mooderate frost } \\
\text { potential }\end{array}$ & 150 to 200 & 4000 to 5700 & 20 to 60 \\
\hline Sand & $\begin{array}{l}\text { SW. SP. GP-GM. } \\
\text { and GM }\end{array}$ & $\begin{array}{l}\text { Good support and excellent } \\
\text { drainage characteristics } \\
\text { with very slight frost } \\
\text { potential }\end{array}$ & 150 to 200 & 4000 to 5700 & 10 to 40 \\
\hline Silty sand & $\begin{array}{l}\text { SM. non-plastic } \\
\text { (NNP), and } 15 \% \text {. } \\
\text { silt (minus } \# 200 \text { ) }\end{array}$ & $\begin{array}{l}\text { Poor support and poor } \\
\text { drainage with very high } \\
\text { frost potential }\end{array}$ & 100 to 150 & 2700 to 4000 & 5 to 30 \\
\hline Silty sand & $\begin{array}{c}\text { SM, Plasticity } \\
\text { Index }(\mathrm{PI}=10 \% \text {, and } \\
=35 \% \text { silt }\end{array}$ & $\begin{array}{l}\text { Poor suppoit and fair to } \\
\text { poor drainage with } \\
\text { moderate to hight frost } \\
\text { potential fros } \\
\end{array}$ & 100 to 150 & 2700 to 4000 & 5 to 20 \\
\hline Silt & $\begin{array}{l}\text { MI, }>50 \% \text { silt, } \\
\text { liquidid limit }<40 \\
\text { and PI }<10\end{array}$ & $\begin{array}{l}\text { Poor support and } \\
\text { impervious drainage with } \\
\text { very high frost value }\end{array}$ & So to 100 & 1000 to 2700 & 1 to 15 \\
\hline Clay & $\begin{array}{l}\text { CL, liquid limit } \\
>40 \text { and } \mathbf{P I}>10\end{array}$ & $\begin{array}{l}\text { Very poor support and } \\
\text { impervious drainage wwith } \\
\text { high frost potential }\end{array}$ & 50 to 100 & 1000 to 2700 & 1 to 15 \\
\hline
\end{tabular}

(a)

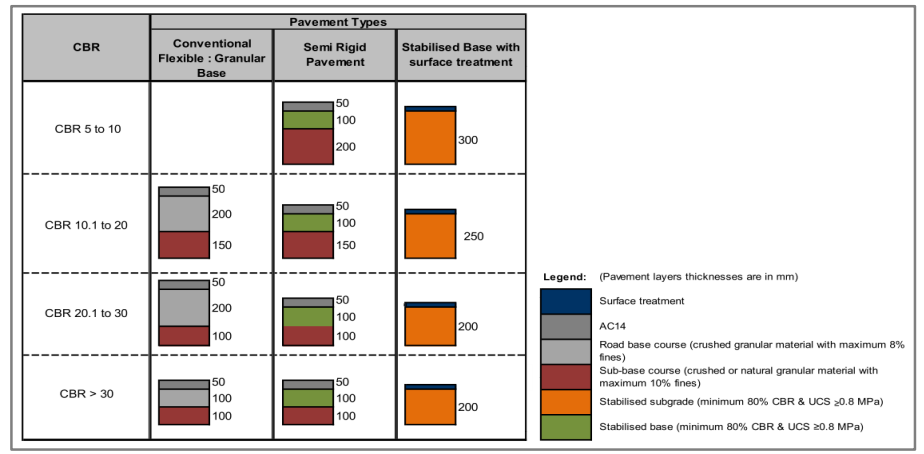

(b)

Fig. 5. (a) Suitability as subgrade [9] (b) JKR guide for selection of alternative pavement structure [10]

Table 1. Overview of some emerging alternative sustainable fills.

\begin{tabular}{|c|c|}
\hline $\begin{array}{c}\text { Alternative Composite Material \& } \\
\text { Production Method }\end{array}$ & $\begin{array}{c}\text { Functional use, Technical Properties } \\
\text { \& Approximate Costs }\end{array}$ \\
\hline $\begin{array}{l}\text { Foamed recycled glass [13]; } \\
\text { Low weight foamed recycled glass aggregates of } \\
\text { up to } 40 \mathrm{~mm} \text { in size }\end{array}$ & $\begin{array}{l}\text { Non-structural fills in embankments, Retaining wall backfill } \\
\text { and pipe bedding; } \\
\text { Gap graded materia ; } \\
\text { Max. Dry density }=2.84 \mathrm{kN} / \mathrm{m}^{3} ; \text { LA Abrasion }=94 \%\end{array}$ \\
\hline $\begin{array}{l}\text { Recycled Asphalt Pavement(RAP) - Fly } \\
\text { ash(FA) Geopolymer [14] } \\
\text { A } 30 \% \mathrm{FA} \text { mixture and a } 50: 50 \text { ratio of } \mathrm{NaOH} \\
\text { and } \mathrm{Na} 2 \mathrm{SiO} 3 \text { is used at } 40 \mathrm{C} \text { curing temperature }\end{array}$ & $\begin{array}{l}\text { Stabilized pavement base course material; } \\
\text { Compressive strength }=5.3 \mathrm{MPa} \\
\text { Fly Ash } 1 \text { tonne }- \text { Price insignificant. Transporation cost and safety } \\
\text { certificate required due to hazardous nature. }\end{array}$ \\
\hline $\begin{array}{l}\text { Cement-treated sand and expanded } \\
\text { polystyrene (EPS) beads [15] EPS beads are } \\
\text { heated with steam to expand } 50 \text { times its original } \\
\text { size. Cement binds sand and EPS. }\end{array}$ & $\begin{array}{l}\text { Backfill material for use in highway embankments in soft soil } \\
\text { areas } \\
\text { Compression Strength }=800 \mathrm{KPa} \\
\text { Unit Weight }=10 \mathrm{kN} / \mathrm{m}^{3}\end{array}$ \\
\hline $\begin{array}{l}\text { Clays Modified with Recycled Crumb } \\
\text { Rubber [16] } \\
\text { Kaolin clay and bentonite were used as soils for } \\
\text { modification. } 2-4 \% \text { of rubber crumbs give } \\
\text { maximum strength. }\end{array}$ & $\begin{array}{l}\text { Soil modification } \\
\text { Max dry density }=1296 \mathrm{~kg} / \mathrm{m}^{3} \\
\text { Max. Strength }=482 \mathrm{kPa}\end{array}$ \\
\hline $\begin{array}{l}\text { Blast furnace slag [17] } \\
\text { The cooled slag is transported to a crushing and } \\
\text { screening plant for further processing into various } \\
\text { products including aggregates. }\end{array}$ & $\begin{array}{l}\text { As fill material for subgrade, sub-base or base. } \\
\text { Particle Density }=2,550-2,650 \mathrm{~kg} / \mathrm{m}^{3} \\
\mathrm{LA} \text { abrasion }=37-43 \% \\
\mathrm{OMC}=8-12 \% ; \text { RM } 50.10 / \text { metric tonne }\end{array}$ \\
\hline $\begin{array}{l}\text { Geofoam [18] } \\
\text { Polymerization of styrene monomer is followed } \\
\text { by impregnation of the polymerized polystyrene } \\
\text { beads with a blowing agent. Styrene monomer and } \\
\text { water is charged to the reaction kettle equipped } \\
\text { with an agitator. }\end{array}$ & $\begin{array}{l}\text { As fill material for highways and embankments on peat or } \\
\text { soft soil. } \\
\text { Min. density }=15 \mathrm{~kg} \mathrm{~m}^{3} ; \text { Compressive stress }=60-110 \mathrm{kPa} \\
\text { Flexural strength }=60-300 \mathrm{kPa} \\
\text { Shear strength }=80-130 \mathrm{kPa} ; \text { Tensile strength }=110-290 \mathrm{kPa} \\
1.2 \mathrm{~m} \times 1.8 \mathrm{~m} \times 0.6 \mathrm{~m} \sim \mathrm{RM} 300.0\end{array}$ \\
\hline
\end{tabular}




\section{Alternative and lightweight fill technology}

Wijeyesekera et al [19] designed the compacted clay surround barrier for the Heathrow Express Tunnel (portion passing through an old landfill site) to prevent methane and other environmentally hazardous material from the landfill penetrating the box tunnel in the form of gas, solid or as them dissolved in the landfill leachate. They adopted a sustainable approach of reusing (with strict moisture conditioning) the London clay being excavated from a nearby shaft for Terminal 4 construction. The three main acceptance criteria for the compacted clay surround (Fig. 6) were; to achieve a low permeability in the clay fill of less than $10^{-9} \mathrm{~m} / \mathrm{s}$, swelling pressures to be less than the horizontal stress caused by the overburden, and the fill to be flexible in accepting a degree of differential movement without fissuring or cracking. As shown in Fig. 6, this was achieved with strict compaction and moisture control of three specific layers of fill at plastic limit (PL) of 1.1PL, 1.2PL and 1.3PL. Additional environmental gas venting and post construction deformation monitoring provisions are also shown in Fig. 6.

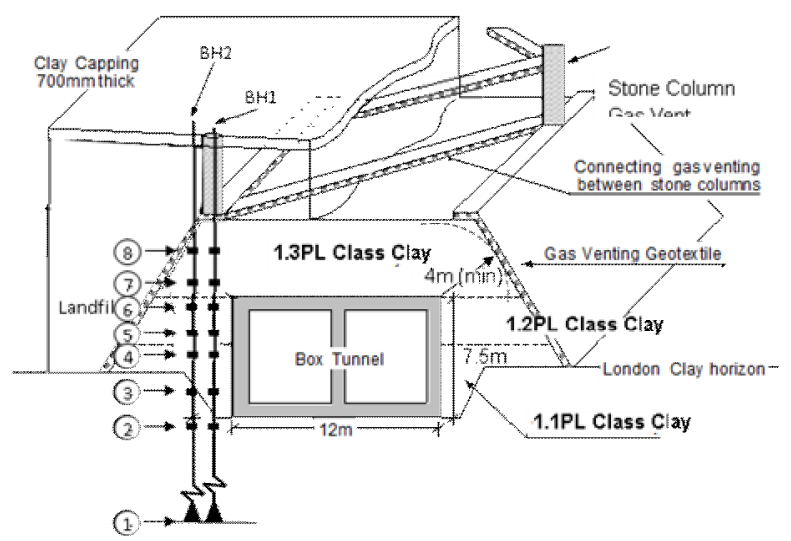

Fig. 6. Compacted Clay Liner (Fill) surround for Heathrow Express Tunnel [19]

Further technology to mitigate settlement has been the intuitive adoption of bio engineering concepts in using natural material (tree trunks- logs or bamboo) to reinforce the embankments. Fig. 7(a) illustrates a 2500 BC Babylonian technology[20], where hewn tree trunks were laid on yielding subgrade to form a permeable and stiffened / reinforced subbase (but lacking monolithic rigidity found in reinforced concrete).

Somewhat similar bio engineering concept is further seen in a case study reported by Priyadarshee et al [21] who reviewed construction of a low-volume semi rigid pavement with the provision of a grid of bamboo as soil reinforcement(A bamboo mesh 250x250mm placed on $100 \mathrm{~mm}$ wooden spacers). Such practice is being popularly used in current construction with the additional use of geofabrics separating the reinforced bamboo cages and interspersed with sand layers (Fig. 7(b)).

Environmentally friendly adoption of used tyres as tyre bales or mats (Fig. 8(a) and 8(b)) over soft ground demonstrates the need for a stiffer but lightweight infill to the subgrade or embankment. Tyre bales measure approximately $1.3 \times 1.55 \times 0.8 \mathrm{~m}$. Tyre mat manufacture is more labour intensive and its length can be custom made while the width (tyre circumference) and the thickness (tyre width) are fixed with the split tyres held together by steel rods. Fig. 8(c) [22] illustrates the some of the potential applications in highway structures. As seen in Fig. 8(d), geotextiles are used as appropriate surrounds to restrict the movements of fines between the regulating sand layers and the ground. 


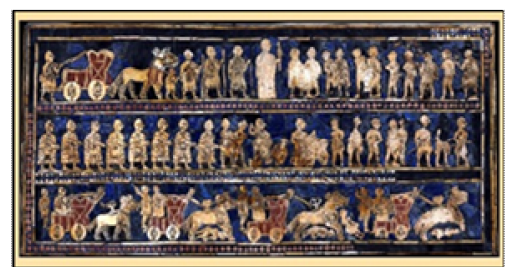

(a)

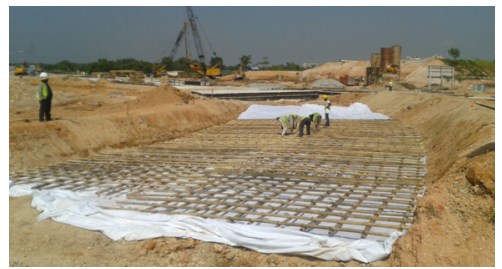

(b)

Fig. 7. Technology with a bio engineering concept; (a) Early road construction in Ur - adopted from [20]; (b) Bamboo grid and cell reinforcement - construction site in Selangor, photographed by author.

Blocks of expanded Polystyrene (EPS) have been used extensively in Malaysia to remedy the settlement in approach road embankments (Bridge abutments). EPS is popularly used in the form of a lightweight $\left(<50 \mathrm{~kg} / \mathrm{m}^{3}\right.$, dry density) block material, to mitigate settlement by reducing gravitational self-loading.

(c)

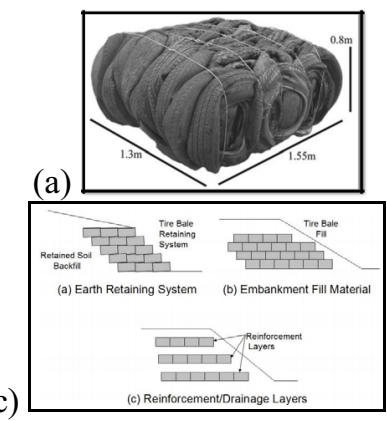

(b)

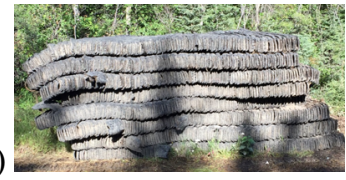

(d)

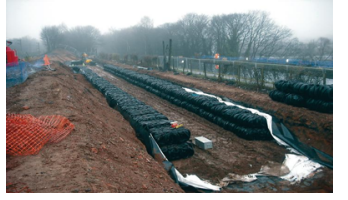

Fig. 8. Sustainable, environmentally appropriate fill technology; (a) Tyre bales [23] (b) Tyre mat photographed by author (c) Proposed uses of tyre bales [22] (d) Construction site [22]

The very low density of the EPS makes it vulnerable to high buoyancy forces [24]. EPS is a combustible material and there are instances of failures caused by fire.

\section{Conclusions}

A variety of lightweight fill materials and emerging technologies have been studied and presented in this paper circumspectly. The importance of the fill being lightweight was highlighted through examples of various alternative fill technologies in practise. Furthermore, by using composite and existing lightweight materials as alternative fill material, it contributes in achieving the necessary balance between economics and sustainability, thus an effective replacement for the conventional fill.

\section{References}

[1] The Manitoba Water Service Board, Standard Construction Specifications Section 022180, Pipe Excavation, Bedding and Backfill, (2013)

[2] D. Daud, P.C. Tan, M. Lee, D.Q.Wu, Green and quality rural roads in Malaysia, Proc. $7^{\text {th }}$ Int. Conf. on Road and Airfield Pavement Technology, 1-8 (2011)

[3] R.S. Kirby, Engineering in History, Pubs. Courier Corporation, (1990) 
[4] New Strait Times, 27th September (2011)

[5] U.S. Department of Transportation FDHA, Gravel Roads - Maintenance and Design Manual, South Dakota Local Transport Assistance Program, (2000)

[6] New Zealand Research Council, Dust - Nuisance Issues, Retrieved on October 2016 www.nrc.govt.nz/environment/air/issues/dust nuisance

[7] Federal Highways Authority, Gravel Roads, FHWA-RD-97-148, US Department of Transportation, (1997)

[8] American Pavement Concrete Association, Asphalt Roads, Asphalt Paving Association, Ohio, (1996)

[9] Jabatan Kerja Raya, Pavement Design Guide, Kuala Lumpur, (2012)

[10] D.C. Wijeyesekera, D. Newport, K. Edwards, Manufactured Aggregate as improved backfill material for plastic pipes, Plastic Pipes XII, Italy, (2004)

[11] V. Corinaldesi, A. Nardinocchi, J. Donnini, Reuse of recycled glass in mortar manufacturing, European Journal of Environmental and Civil Engineering, (2016)

[12] A. Arulrajah, M.M. Disfani, F. Maghoolpilehrood, S.Horpibulsuk, A.M. Udonchal, Imteaz, Y.J. Du, Engineering and environmental properties of foamed recycled glass as a lightweight engineering material, Journal of Cleaner Production, 94, 369-375 (2015)

[13] M. Menglim Hoy, S. Horpibulsuk, A. Arulrajah, Strength development of recycled asphalt pavement - Fly ash geopoly mer as a road construction material, Construction and Building Materials, 117, 209-219 (2016)

[14] F. Wang, L. Miao, A proposed lightweight fill for embankments using cement-treated Yangzi River sand and expanded polystyrene (EPS) beads, Bull Eng Geol Environ, 68, 517-5(2009)

[15] B. Beena Ajmera, B. Tiwari, J. Koirala, Geotechnical properties of clays modified with recycled crumb rubber, Geotechnical and Structural Engineering Congress, ASCE, (2016)

[16] Australasian Slag Association, A Guide to the Use of Slag in Roads, (2002)

[17] A.F. Elragi, Selected engineering properties and applications of EPS geofoam, ProQuest Disssertations and Theses, (2000)

[18] D.C. Wijeyesekera, K. O'Connor, D.E. Salmon, Design and performance of a compacted clay barrier through a landfill, Engineering Geology, 60-4, 295-306 (2001)

[19] Information retrieved from http://sunerianshakespeare.com/mediac/450-0/.jpg (2011)

[20] A. Priyadarshee, A.K. Chhotu, V. Kumar, Use of bamboo in low volume rigid pavement as reinforced material: A review. Journal of Civil Engineering and Environmental Technology, 1(3), 14-16 (2014)

[21] B. Freilich, J.G Zornberg, Mechanical Properties of Tire Bales for Highway Applications, Technical Report for Texas Department of Transportation and the Federal Highway Administration, (2009).

[22] C. Mackenzie, T. Saareketo, Use of recycled tyre bales in a lightweight road embankment over peat, Research Report THE B 871, Road Scanners, (2003)

[23] J.S. Horvath, Geofoam fills and the non-issue of buoyancy. Lessons learned from failure involving geofoam in roads and embankments, Report No. CE/GE -99-1 Civil Engineering Manhattan College, (1999) 